УДК 629.423.31

\title{
МІКРОПРОЦЕСОРНЕ КЕРУВАННЯ ЧАСТОТНИМ ПЕРЕТВОРЮВАЧЕМ
}

\author{
А.О. Габінський, канд. техн. наук С.Г. Буряковський \\ МИКРОПРОЦЕССОРНОЕ УПРАВЛЕНИЕ ЧАСТОТНЫМ \\ ПРЕОБРАЗОВАТЕЛЕМ
}

\section{А.А. Габинский, канд. техн. наук С.Г. Буряковский \\ MICROPROCESSOR CONTROL FREQUENCY CONVERTERS}

\author{
A.A. Habinskyy, cand. of techn. sciences S.G. Buryakovskyy
}

Цифрова реалізація системи керування електроприводом потребує від обчислювача високої продуктивності, у результаті чого більшість приводів зарубіжних фірм виконано на прочесорах ичифрової обробки сигналів. Майже всі із таких мікропрочесорів мають на своєму кристалі підсистему вводу аналогових сигналів, велику кількість дискретних входів/виходів, таймери, апаратний широтно-імпульсний модулятор для інвертора. Перетворювач частоти виконаний на базі дворівневого інвертора напруги з використанням IGBT транзисторів.

Ключові слова: електропривод, мікропрочесор, счгнал, модулятор, інвертор, фазна напруга, асинхронний двигун, транзистор, перетворювач.

Цифровая реализация системы управления электроприводом требует от вычислителя высокой производительности, в результате чего большинство приводов зарубежных фирм выполнены на прочессорах циифровой обработки сигналов. Почти все из таких микропроцессоров имеют на своем кристалле подсистему ввода аналоговых сигналов, большое количество дискретных входов/выходов, таймеры, аппаратный ииротноимпульсный модулятор для инвертора. Преобразователь частоты выполнен на базе двух уровневого инвертора напряжения с использованием IGBT транзисторов.

Ключевые слова: электропривод, микропроиессор, сигнал, модулятор, инвертор, фазное напряжение, асинхронный двигатель, транзистор, преобразователь.

Digital implementation of the control system electric calculator requireshigh performance, resulting in the majority of occasions foreign companies executed on Digital Signal Processor. Almost all of these microprocessor shave on your chip subsystem input analog signals, a large number of discrete I / $O$, timers, hardware pulse-width modulator for an inverter. Frequency converteris made on a two-level voltage inverterusing IGBT transistors.

Keywords: elktropryvid, microprocessor, signal, modulator, inverter, phase voltage, induction motor, tranny, converter. 
Масове поширення керованих приводів на базі силових перетворювачів частоти викликало появу цілого ряду спеціалізованих мікропроцесорів, орієнтованих для роботи в таких пристроях.

Цифрова реалізація системи керування електроприводом потребує від обчислювача високої продуктивності, в результаті чого більшість приводів зарубіжних фірм виконано на процесорах цифрової обробки сигналів. Майже всі із таких мікропроцесорів мають на своєму кристалі підсистему вводу аналогових сигналів, велику кількість дискретних входів/виходів, таймери, апаратний широтно-імпульсний модулятор (ШІМ) для інвертора.

Перетворювач частоти можемо виконати на базі дворівневого інвертора напруги. Такий інвертор напруги реалізується на базі IGBT транзисторів. Нумерація ключів та принцип їх переключення показано на рис. 1 та 2 відповідно. На виході такого АІН формується двоступенева на половинному значенні періоду загальна крива фазної напруги.

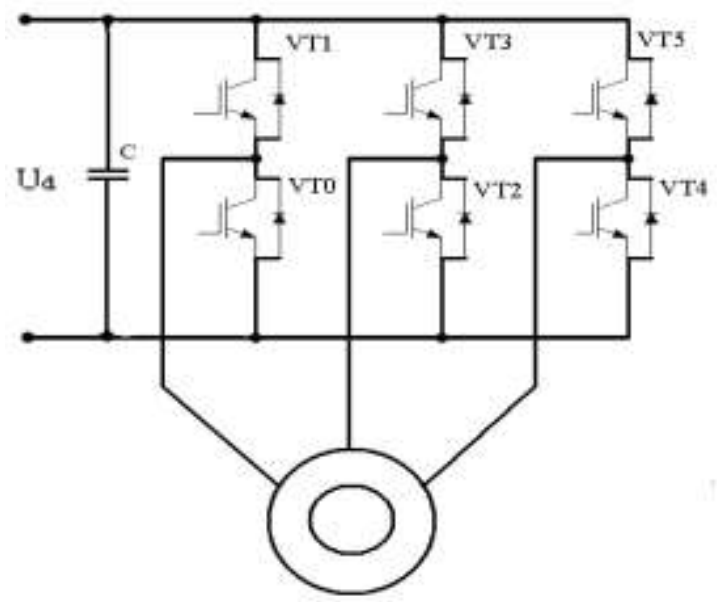

Рис. 1. Трифазний дворівневий мостовий інвертор напруги

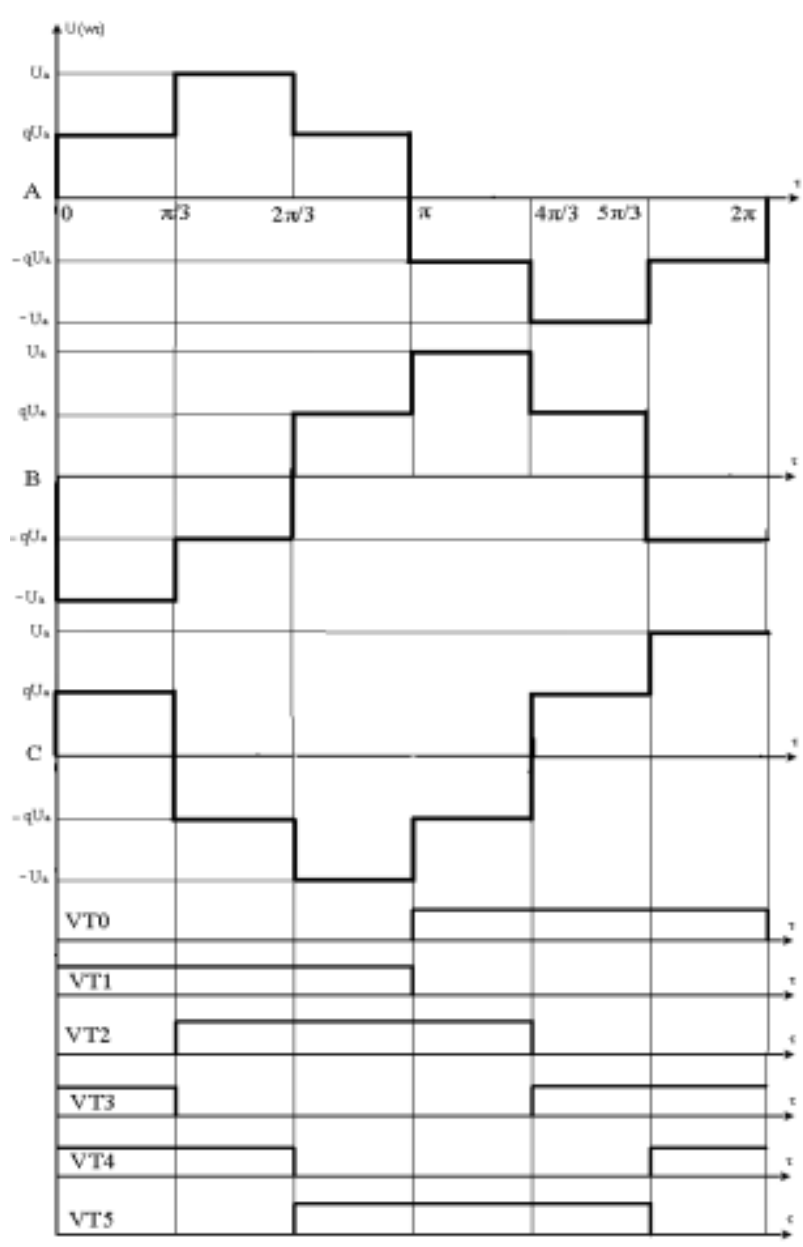

Рис. 2. Принцип керування дворівневого АІН

На рис. 3 показано схемне виконання системи керування інвертором. На входи $10,12-14$ подається постійна напруга від випрямляча та згладжуючого фільтра. Виходи 2, 5, 8 приєднуються до трифазного асинхронного двигуна. За допомогою входів 15-16 через драйвер IC здійснюється подача сформованих імпульсів на відповідні ключі інвертора (HIN1-3 управління ключами високого рівня; LIN1-3 - управління ключами низького рівня). На входи 22, 23 подається живлення самого драйвера.

Систему керування побудуємо на базі мікропроцесора. Сучасні мікропроцесори мають складну структуру та містять велику кількість електронних елементів та компонентів 3 великою кількістю зв'язків між ними. 


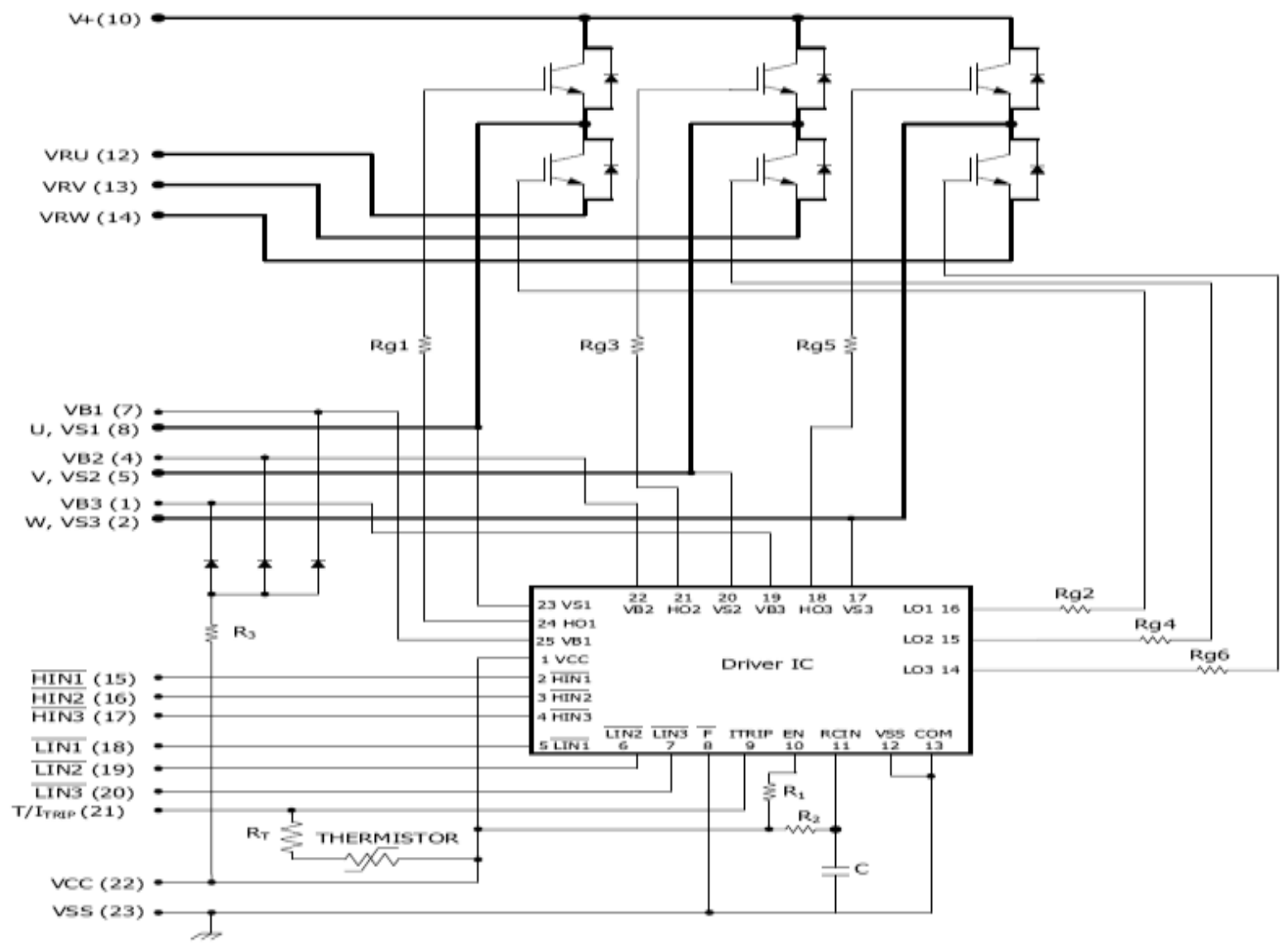

Рис. 3. Схемне виконання системи керування інвертором

Для цього візьмемо мікроконтролер американської фірми Microchip pic18×2431 (рис. 4).

Цей мікроконтролер містить: арифметично-логічний пристрій (АЛП); регістр загального призначення; регістр ознак; регістр для підрахунку команд; аналого-цифровий перетворювач (АЦП); три порти вводу-виводу А, В, С; три таймери; регістри скидання; спеціальний регістр настройки ШІМ.

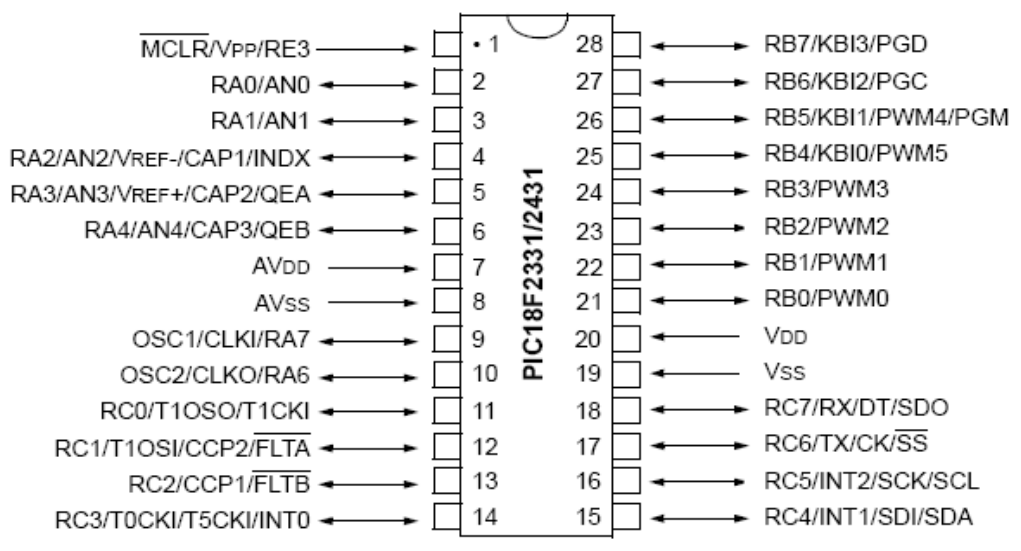

Рис. 4. Мікроконтролер ріс18х2431 
Даний мікроконтролер має 28 ніг (виводів). Із них 24 ноги використовуються для вводу або виводу інформації. При певній настройці мікроконтролера ноги 2-5 можуть бути використані як аналогові входи. Живлення мікроконтролера підводиться на ноги 19 та 20 (- та + відповідно). Величина напруги - +5 В.

Для того, щоб прошити мікроконтролер заздалегідь написаною для нього програмою, необхідний спеціальний мікрочипівський програматор. Ноги 1, 19, 20, 27 та 28 припаюють до п’ятижильної шини, яку в свою чергу приєднують до програматора. Інший його вихід вводять в USB-вхід комп'ютера.

Ноги 21-26 підключають до відповідних виводів драйвера. Керування частотою обертання ротора асинхронного двигуна будемо здійснювати шляхом зміни величини фазної напруги та іï частоти, зберігаючи при цьому основний закон частотного управління ( $U=$ const $^{--}$змі-

$$
\frac{u}{f}=\text { const }
$$

нювати величину напруги необхідно пропорційно до зміни іiі частоти). Регулювання напруги здійснюємо завдяки ШІМ, як показано на рис. 5.

Збільшуючи величину імпульсу на одному і тому ж періоді ШІМ ми одночасно збільшуємо середнє значення вихідної напруги. Частоту можна регулювати завдяки інтенсивності переключення ключів (в мікроконтролері - це інтенсивність скидання таймера).
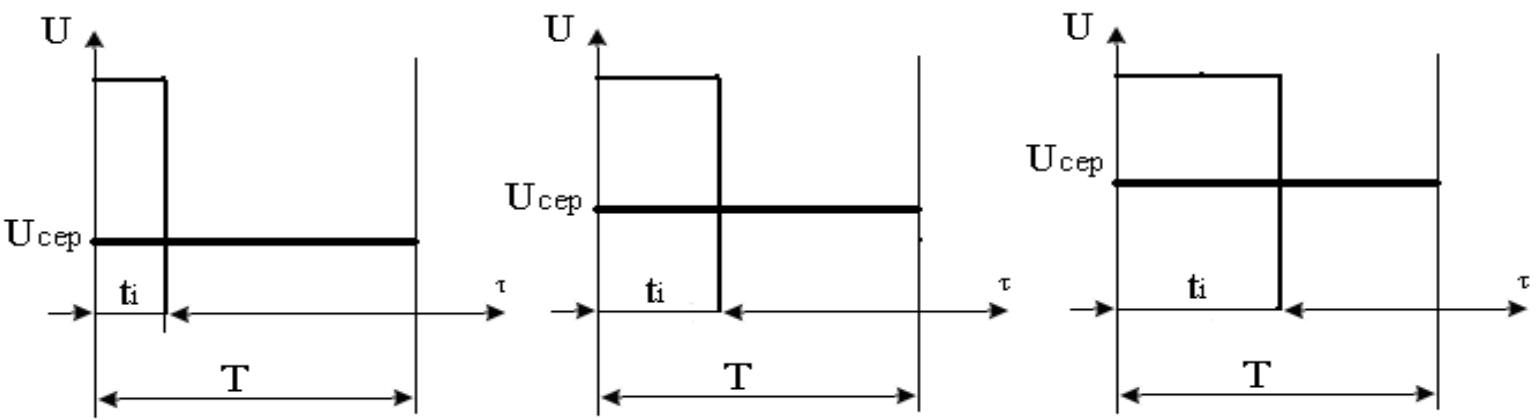

Рис. 5. Діаграма регулювання напруги

\section{Список використаних джерел}

1. Андреев, В.П. Основы электропривода [Текст]: учебник / В.П. Андреев, Ю.А. Сабинин. - М.: ГОСЭНЕРГОИЗДАТ, 1963. - 772 с.

2. Бурков, А.Т. Электронная техника и преобразователи [Текст]: учеб. для ВУЗов ж.-д. трансп. / А.Т. Бурков. - М.: Транспорт, 1999. - 464 с.

3. Ключев, В.И. Теория електропривода [Текст] / В.И. Ключев. - М.: Енергоатомиздат, 1985. $-560 \mathrm{c}$.

4. Теория электрической тяги [Текст] / В.Е. Розенфельд, И.П. Исаев, Н.Н. Сидоров, М.И. Озеров; под ред. И.П. Исаева. - М.: Транспорт, 1995. - 294 с.

5. Чиликин, М.Г. Общий курс электропривода [Текст] / М.Г. Чиликин, А.С. Сандлер. М.: Энергоиздат, 1981. - 567 с.

Рецензент д-р техн. наук, професор А.П. Фалендиш

Габінський Артем Олександрович, слухач ІППК, гр. МЗ-ЕТ-Б-11.

Буряковський Сергій Геннадійович, канд. техн. наук, доц. кафедри автоматизованих систем електричного транспорту.

Habinskyy A.A., Buryakovskyy S.G., cand. of techn. sciences. 